\title{
DETECTION OF Drechslera avenae IN OAT SEEDS
}

\author{
NADIA C. LÂNGARO, ERLEI M. REIS \& ELMAR L. FLOSS \\ Faculdade de Agronomia e Medicina Veterinária, Universidade de Passo Fundo, Cx. Postal 566, \\ CEP 99001-970, Passo Fundo, RS, Brasil, e-mail: langaro@ginet.com.br
}

(Accepted for publication on 12/06/2001)

Corresponding author: Nadia Canali Lângaro

LÂNGARO, N.C., REIS, E.M. \& FLOSS, E.L. Detection of Drechslera avenae in oat seeds. Fitopatologia Brasileira 26:745-748. 2001.

\begin{abstract}
The fungus Drechslera avenae, the causal agent of Helminthosporium leaf spot on oats (Avena sativa), survives as mycelium in crop residues and in infected seeds. In trials carried out in the laboratory, ten methods were evaluated for their efficiency to detect $D$. avenae in oat seeds. In each experiment, groups of two or three methods were compared to a standard protocol, in which seeds were placed in Petri dishes containing the Reis selective medium and incubated at $25 \pm 2{ }^{\circ} \mathrm{C}$ for ten days. Data were submitted to analysis of variation and the

means of the methods were compared using the Dunnett test at the 5\% significance level. Overall, the highest levels of seed infection by $D$. avenae were observed on oat seeds plated in the osmotic, the oat-agar and the Reis media, or on seeds subjected to heat treatment previous to incubation in malt-agar. Therefore, these methods should be recommended for detection of $D$. avenae in oat seed testing.

Additional Key words: Deuteromycetes, Pyrenophora avenae and, detection methods.

\section{RESUMO}

Deteç̧ão de Drechslera avenae em sementes de aveia

O fungo Drechslera avenae, agente causal da helmintosporiose da aveia (Avena sativa), sobrevive como micélio em restos culturais e em sementes infetadas. Em ensaios conduzidos em laboratório, dez métodos foram avaliados considerando-se sua eficiência em detectar $D$. avenae em sementes de aveia. Em cada experimento, grupos de dois ou três métodos foram comparados a um padrão, no qual as sementes foram dispostas em placas de Petri contendo meio seletivo de Reis e incubadas a $25 \pm 2{ }^{\circ} \mathrm{C}$ por dez dias.

Os dados foram submetidos à análise de variância e as médias comparadas pelo teste de Dunnett (5\%). Entre os métodos testados, maiores níveis de infecção de $D$. avenae foram observados nas sementes dispostas nos meios ou métodos osmótico, aveia-ágar e seletivo de Reis, ou no qual as sementes foram aquecidas previamente à incubação em malte-ágar. Sugerem-se que, em análise de sanidade de sementes de aveia, sejam utilizados esses métodos para a detecção de $D$. avenae.
\end{abstract}

\section{INTRODUCTION}

The white oat (Avena sativa L.), a cereal of the Gramineae family, is mainly cultivated in temperate climate regions. It is grown with the purpose of producing grain, green pasture, and hay, and as a winter cover crop for no-till farming. The grain is used for animal feeding and for human consumption as flakes, flour, and bran (Floss, 1991).

Among the factors that reduce grain production and the quality of oat is the Helminthosporium leaf spot, caused by the fungus Drechslera avenae (Eidam) Sharif (teleomorph = Pyrenophora avenae Ito \& Kurib). This disease occurs in most oat producing areas (Reis \& Soares, 1995) and the pathogen survives as mycelium in oat crop residues (Shaner, 1981; Kohli \& Reis, 1994) and in infected seeds. Seeds are the main source of inoculum, especially in field areas cultivated under crop rotation (Turner \& Millard, 1931).

The efficiency of methods for detecting of $D$. avenae in oat seeds can be influenced by the amount and position of the inoculum in the seed, by the presence of antagonists and by environmental factors (Soteros \& Sheridan, 1972). The first known detection method for $D$. avenae was the filterpaper, developed by Muskett (1938). In this method, the inconvenient growth of antagonist fungi and bacteria is a major disadvantage that has led many authors to search for more accurate protocols (Soteros \& Sheridam 1972; Chidambaram et al., 1974; Elekes, 1983; Mathur, 1983; and Reis, 1983).

Some species of Bipolaris and Drechslera produce pigments, called anthraquinones, in culture media (Sivanesan, 1987). Brodal (1993), using the method developed by Joelsson (1983), observed production of a fluorescent blue pigment on filter-paper after incubating oat seeds infected by $D$. avenae.

Molecular markers such as RAPD (random amplified polimorphic DNA) and RFLP (restriction fragment length polymorphism), have been developed for genetic studies on the causal agents of fungal diseases in wheat (Triticum 
N.C. Lângaro et al.

aestivum L.) (Faris et al., 1997), barley (Hordeum vulgare L.) (Valè et al., 1994; Graner et al., 1996) and oat (Avena sativa L.) (Chong et al., 1994). These techniques could be extended to routine seed testing of specific fungal infections, including $D$. avenae.

In eradication tests of seed-borne pathogens, when seeds are treated with an efficient fungicide, pathogens are present in very low incidence and cannot be detected by health tests, such as the filter-paper. The objective in this research was to test ten laboratory methods in order to select the most sensible for detection of $D$. avenae in seed eradication tests.

\section{MATERIALS AND METHODS}

To select the most efficient method for $D$. avenae detection, ten protocols were compared in four laboratoryconducted experiments. The various protocols were organized in groups of two or three and compared to the same standard method, the Reis selective medium (Reis, 1983). In all tests seeds of the UPF 17 cultivar were used. In each substrate seeds were placed at similar distances from each other, for a total of ten seeds per $9 \mathrm{~cm}$ Petri dish. This work was done in a laminar flow hood and forceps were very often flamed. Plates were then sealed and incubated for seven days at $25 \pm 2$ ${ }^{\circ} \mathrm{C}$ and a $12 \mathrm{~h}$ photoperiod (except for the heating, osmotic, pigment, and Reis methods). In tomato-extract-agar, filterpaper, potato-sucrose-agar (PSA), filter-paper + nylon sponge disc, oat-agar, and V8-agar, 200 ppm of streptomycin sulfate were added to the substrate. In these methods, seeds were previously disinfested in sodium hypochloride at $2 \%$ (Fernandez, 1993). After colony development, fungus structures were examined under a stereo microscope for the identification of $D$. avenae. Seeds on which the fungus formed conidiophore and conidium were considered infected. The following methods were tested:

\section{Experiment 1}

(a) Tomato-extract-agar (Fernandez, 1993): seeds were plated in tomato-extract-agar $(200 \mathrm{ml}$ tomato extract; $3 \mathrm{~g}$ $\mathrm{CaCO}_{3}, 15 \mathrm{~g}$ agar and $1000 \mathrm{ml}$ sterile distilled water); (b) filter-paper (Chidambaram et al., 1974): seeds were distributed over three sterile filter-paper layers embedded with water; and (c) standard Reis selective medium for isolation of Cochliobolus sativus (Ito \& Kurib) Drech. ex Dastur (Reis, 1983): seeds were distributed on a PSA medium (15 g potato; $25 \mathrm{~g}$ sucrose; $10 \mathrm{~g}$ agar; and $700 \mathrm{ml}$ distilled water) amended with $50 \mathrm{ppm}$ of benomyl, $500 \mathrm{ppm}$ of streptomycin sulfate, $300 \mathrm{ppm}$ of neomycin sulfate, $3 \mathrm{ml}$ of captan (stock solution $=133,33 \mathrm{mg} / 100 \mathrm{ml}$ of sterile distilled water), and $5 \mathrm{ml}$ of botran (dicloran) (stock solution $=200 \mathrm{mg} / 100 \mathrm{ml}$ of sterile water).

\section{Experiment 2}

(a) PSA (200 g potato, $20 \mathrm{~g}$ sucrose, and $15 \mathrm{~g}$ agar in $1000 \mathrm{ml}$ sterile distilled water) (Fernandez, 1993); (b) filter- paper + nylon sponge disc (5 $\mathrm{mm}$ in thickness) was placed below three filter-paper layers to maintain moisture; and (c) the standard protocol as described previously.

\section{Experiment 3}

(a) Heat treatment (Malone, 1962): seeds were placed on sterile glass Petri dishes and heated in a circulating air oven at $100{ }^{\circ} \mathrm{C}$, for $1 \mathrm{~h}$. Afterwards, seeds were cooled to ambient temperature and then plated in malt-agar medium (Soteros \& Sheridan, 1972); (b) oat-agar (100 g oat flour and $15 \mathrm{~g}$ agar in $1000 \mathrm{ml}$ distilled water) (Fernandez, 1993); and (c) the standard described previously.

\section{Experiment 4}

(a) Osmotic (Brodal, 1993, adapted from Joelsson, 1983): seeds were placed on glass Petri dishes, heated to $90{ }^{\circ} \mathrm{C}$ for $2 \mathrm{~h}$, and cooled to ambient temperature. The seeds were then placed over three filter-paper layers and dipped in a $0,5 \mathrm{M}$ sucrose solution $(170 \mathrm{~g}$ of cane sugar per litre of distilled water) for a few seconds. After seven days, in alternating $16 \mathrm{~h}$ - periods at $27 \pm 1^{\circ} \mathrm{C}$, under white light $(5.000$ to $6.000 \mathrm{Lux}$ ), and $8 \mathrm{~h}$ at $21 \pm 1{ }^{\circ} \mathrm{C}$ in the dark, seeds were removed and the filter-paper was sprayed with an $1 \% \mathrm{NaOH}$ solution; (b) V8-agar (200 $\mathrm{ml} \mathrm{V8} \mathrm{juice,} 3 \mathrm{~g} \mathrm{CaCO}_{3}$, and $15 \mathrm{~g}$ agar in $1.000 \mathrm{ml}$ distilled water) (Fernandez, 1993); (c) pigments (Knudsen, 1982, for Pyrenophora graminea (Rabh.) Ito \& Kurib and P. teres (Died.) Drech. in barley): seeds were disinfested by immersion in sodium hypochloride for $10 \mathrm{~min}$ and then distributed in Petri dishes over three layers of filterpaper moistened with $12 \mathrm{ml}$ of $0,04 \%$ acetic acid; were incubated at $18-23{ }^{\circ} \mathrm{C}$, for $48 \mathrm{~h}$, followed by $25 \mathrm{~h}$ at $-20^{\circ} \mathrm{C}$, and 12 days at $12-16^{\circ} \mathrm{C}$ in a $12 \times 12$ dark-ultraviolet light (400 lux) cycle; after incubation, the filter-paper was examined for presence of pigments and D. avenae spores; and (d) standard as described before.

\section{Experiment 5}

This experiment was carried out to examine the selectivity of the osmotic method and to differentiate the colour pigment produced by $D$. avenae from those of other Drechslera and Bipolaris species. Wheat (Emprapa 40 cultivar), barley (MN 697 and BR 2 cultivars), and oat seeds (UPF 17 cultivar), were tested by the osmotic method as compared to the BSA and Reis methods; a total of 12 treatments were tested. Two hundred seeds were used for each treatment (five plates $\times$ four replicates) and incubated under conditions previously described.

\section{Statistical procedures}

In all experiments a completely randomised design was used. Means for methods were submitted to analysis of variation and the incidence of Bipolaris sorokiniana (Sacc. in Sorok) in wheat, of Drechslera teres (Sacc.) Shoem., and Bipolaris sorokiniana in barley, and of $D$. avenae in oat were compared by the Dunnett test $(\mathrm{p}<0,05)$ (Dunnett, 1964). 


\section{RESULTS AND DISCUSSION}

The efficiency of the various methods (Experiments $1,2,3$ e 4 ) in detecting D. avenae in oat seeds is presented in Table 1. In the Reis selective medium, used as the standard protocol, $D$. avenae formed conidiophore and conidia after ten days of seed incubation. There was no need for previous seed disinfestation and plating in laminar flow hoods. However, this medium did not avoid colony formation for $B$. sorokiniana, Alternaria spp., and other Drechslera species.

In experiment 1 (Table 1), sporulation of $D$. avenae initiated after ten days of incubation in tomato-extract-agar and after seven days in filter-paper. Although Petri dishes were sealed with plastic film, the filter-paper did not keep enough moisture throughout the incubation period.

In PSA, experiment 2 (Table 1), Fusarium spp., Alternaria spp., and storage fungi as Penicillium spp. and Aspergillus spp. developed. Observation of $D$. avenae conidia was possible from nine days of incubation. The presence of nylon sponge disc in the filter-paper method, kept enough moisture throughout the incubation period, not needing water reposition. In this method, observation of $D$. avenae sporulation was possible from the $7^{\text {th }}$ day of incubation.

Heating the oat seeds to $100{ }^{\circ} \mathrm{C}$ allowed for the recuperation of $D$. avenae. According to Malone (1962), heating eliminates most contaminating microorganisms, with little or no effect over $D$. avenae. After seven days of incubation, heating made seed examination easy due to the low production of fungus mycelium, and strong, uniform, and typical conidia and conidiophores could been seen. Seeds tested in this method showed only D. avenae colonies. From such results, we conclude that $D$. avenae was the only fungus to survive the tested temperature $\left(100{ }^{\circ} \mathrm{C}\right)$. In oat-agar, evaluations were possible after ten days.

In the osmotic method (Table 1), infected oat seeds

TABLE 1 - Incidence of Drechslera avenae in oat (Avena sativa) seeds as detected by ten seed-testing methods based on four experiments

\begin{tabular}{lcccc}
\hline \multirow{2}{*}{ Method } & \multicolumn{5}{c}{$\begin{array}{c}\text { Experiments } \\
\text { (means)* }\end{array}$} \\
\cline { 2 - 5 } & $\mathbf{1}$ & $\mathbf{2}$ & $\mathbf{3}$ & $\mathbf{4}$ \\
\hline Reis (standard) & $46,00 \mathrm{a}$ & $49,25 \mathrm{a}$ & $44,7 \mathrm{a}$ & $49,25 \mathrm{~b}$ \\
Tomato-extract-agar & $21,50 \mathrm{~b}$ & - & - & - \\
Filter-paper & $11,00 \mathrm{~b}$ & - & - & - \\
PSA & - & $27,25 \mathrm{~b}$ & - & - \\
Filter-paper-sponge** & - & $18,00 \mathrm{c}$ & - & - \\
Heat treatment & - & - & $41,75 \mathrm{a}$ & - \\
Oat-agar & - & - & $36,50 \mathrm{a}$ & - \\
Osmotic & - & - & - & $61,50 \mathrm{a}$ \\
V8-agar & - & - & - & $39,75 \mathrm{c}$ \\
Pigment & - & - & - & $25,00 \mathrm{~d}$ \\
\hline C. V. $(\%)$ & 24,40 & 20,44 & 22,83 & 13,29 \\
L. S. D. (\%) & 16,30 & 7,64 & 11,11 & 7,24 \\
\hline
\end{tabular}

*Means followed by the same letter are not different from each other by the

Dunnett test at $5 \%$ significance.

** Filter-paper + nylon sponge disc

- Treatment not tested in this experiment. did not produce fungal colonies. After incubation, a rose coloured ring was observed on filter-paper around seeds. After removing seeds and spraying the filter-paper with a $\mathrm{NaOH}$ solution, blue pigments formed in 10-30 min. Such results were similar to those described by Brodal (1993). Among all protocols tested in experiments $1,2,3$, and 4 , the highest incidence of the target pathogen was detected by the osmotic method.

In V8-agar (Table 1), the assessment was possible after nine days of seed incubation. The method based on pigment production was laborious and required a longer incubation period. Pigments formed in filter-paper were not clearly seen. Also $D$. avenae grew weakly and did not sporulate in this substrate. Knudsen (1982), in tests with Pyrenophora graminea and $P$. teres, reported the pigment-based method provided a lower index (about 16\%) of detection than the filter-paper + freezing.

In Experiment 5 (Table 2), B. sorokiniana formed a fluorescent lilac pigment when wheat seeds were analysed through the osmotic method and sprayed with $\mathrm{NaOH}$ solution. Blue pigments were also seen in 3\% of the analysed seeds. According to Knudsen (1982) and Brodal (1993), pigments of different colours may form on filter-paper when seeds are infected by more than one species of Drechslera. For barley seeds (cultivar MN 697) plated in the osmotic method, a pale orange pigment formed on filter-paper. Such pigment turned purple after being sprayed with $\mathrm{NaOH}$. Brodal (1993), evaluating Drechslera graminea (Rabh.) Shoem. and D. teres in barley, observed reddish pigments that turned lilac-rose after treatment with $\mathrm{NaOH}$. According to the author, such pigments did not allow for differentiating such Drechslera species. On filter-paper, BR 2 barley seeds formed a light orange pigment, which did not change colour after treatment with $\mathrm{NaOH}$. For oat seeds, a fluorescent blue pigment was again observed on filter-paper, which confirms previously obtained results (Experiment $4 \mathrm{a}$ ). Under these experiment conditions, the osmotic method was selective to $D$. avenae because only seeds infected by this fungus formed blue pigments on filter-paper.

TABLE 2 - Incidence of Bipolaris sorokiniana on wheat (Triticum aestivum) and barley (Hordeum vulgare), Drechslera teres on barley, and Drechslera avenae on oat (Avena sativa) seeds as detected by three seed-testing methods (experiment 5)

\begin{tabular}{|c|c|c|c|c|}
\hline \multirow{2}{*}{ Method } & \multicolumn{4}{|c|}{ Pathogen incidence* } \\
\hline & B. sorokiniana & D. teres $^{2}$ & B. sorokinianả & D. avenae ${ }^{4}$ \\
\hline Osmotic & $17,50 \mathrm{a}$ & $38,00 \mathrm{a}$ & $16,50 \mathrm{~b}$ & $18,00 \mathrm{a}$ \\
\hline PSA & $23,75 \mathrm{a}$ & $43,75 \mathrm{a}$ & $92,75 \mathrm{a}$ & $12,00 \mathrm{~b}$ \\
\hline Reis & $22,75 \mathrm{a}$ & $4720 \mathrm{a}$ & 88,50 a & $15,25 \mathrm{a}$ \\
\hline C. V. $(\%)$ & 17,71 & 10,60 & 7,06 & 14,11 \\
\hline L. S. D. $(\%)$ & 9,64 & 11,66 & 11,87 & 5,43 \\
\hline
\end{tabular}

* Means followed by the same letter are not different from each other by the Dunnett test at 5\% significance.

${ }^{1}$ From cultivar Embrapa 40, wheat; ${ }^{2} \mathrm{MN} 697$, barley; ${ }^{3} \mathrm{BR} 2$, barley; and ${ }^{4} \mathrm{UPF}$ 17 , oat. 
Compared to the standard Reis medium, the osmotic method was the most sensitive for the detection of $D$. avenae. Seed tests such as the heat treatment and the oat-agar did not differ from the standard. Potato-sucrose-agar, tomato-agar extract, filter-paper, filter-paper + nylon sponge disc, pigments and V8-agar were not as good as the standard. Therefore, the osmotic, Reis, oat-agar, and heat treatment methods should be used in oat seed pathology tests.

\section{ACKNOWLEDGEMENTS} appreciated.

The financial support from Capes is greatly

\section{LITERATURE CITED}

BRODAL, G. Osmotic method. Descriptions of seed health testing methods. Norway. STID - Seed Testing Station. 1993.

CHIDAMBARAM, P., MATHUR, S.B. \& NEERGAARD, P. Identification of seed-borne Drechslera species Drechslera avenae (Eidam) Scharif. In: International Seed Testing Association. Hand book of seed health testing. Norway. 1974. pp. 165-168.

CHONG, J., HOWES, N.K., BROWN, P.D. \& HARDER, D.E. Identification of the stem rust resistance gene $P g 9$ and its association with crown rust resistance and endosperm proteins in "Dumont" oat. Genome 37:440447. 1994.

DUNNETT, C.W. "New tables for Multiple Comparisons with a control”. Biometrics 20:482-491. 1964.

ELEKES, P. Methods for detecting hyphal and living fungal infection in wheat seed samples. Seed Science and Technology 11:421-433. 1983.

FARIS, J.D., ANDERSON, J.A., FRANEL, L.J. \& JORDAHL, J.G. RFLP mapping of resistance to chlorosis induction by Pyrenophora tritici-repentis in wheat. Theorical and Applied Genetics 94:98-103. 1997.

FERNANDEZ, M.R. Manual para laboratório de fitopatologia. Passo Fundo. Embrapa-Cnpt. Documentos, 6. 1993.

FLOSS, E.L. Aveia, alternativa para a produção de grãos, pastagem e cobertura verde. Curso de Atualização em Fitotecnia. Piracicaba. Ceres. 1991.

GRANER, A., FOROUGHI, W.B. \& TEKAUZ, A. RFLP mapping of a gene in barley conferring resistance to net blotch (Pyrenophora teres). Euphytica. 91:229-234. 1996.
JOELSSON, G. The osmotic method. A method for rapid determination of seed-borne fungi. Proceedings, $20^{\circ}$ International Seed Testing Association Congress. Ottawa. 1983. pp 1-9.

KNUDSEN, J.C.N. Production of pigments by Pyrenophora graminea and Pyrenophora teres with special reference to the use of this characteristic in seed disease testing. Seed Science and Technology 10:337-363. 1982.

KOHLI M.M. \& REIS, E.M. Wheat Disease Control Strategies work. In: Direct Action National Congress, Villa Giardino. 1994. pp. 214-247.

MALONE, J.P. Studies on seed health. IV. The application of heat to seed oats as an aid in the detection of Pyrenophora avenae by the Ulster method. In: Proceeding of the International Seed Testing Association 27:856-861. 1962.

MATHUR, S.B. Testing seeds of tropical species for seedborne diseases. Seed Science \& Technology 11:113-128. 1983.

MUSKETT, A.E. Biological technique for the evaluation of fungicides. I. The evaluations of seed disinfectants for the control of Helminthosporium diseases of oats. Annals of Botany 2:699-715. 1938.

REIS, E.M. Selective medium for isolating Cochliobolus sativus from soil. Plant Disease 67:68-70. 1983.

REIS, E.M. \& SOARES, R.M. Levantamento, transmissão e controle de fungos patogênicos associados a sementes de aveia. In: Resultados, $15^{\text {a }}$ Reunião da Comissão Sul Brasileira de Pesquisa de Aveia, Guarapuava, PR. 1995. pp. 257-259.

SHANER, G. Effect of environment on fungal leaf blights of small grains. Annual Review of Phytopathology 19:273296. 1981.

SIVANESAN, A. Graminicolous species of Bipolaris, Curvularia, their teleomorphs. Wallinngford. CAB International Mycological Institute. 1987.

SOTEROS, J.J. \& SHERIDAN, J.E. An evaluation of methods for the detection of Pyrenophora avenae Ito and Kuribayashi in New Zealand seed oats. New Zealand Journal of Agricultural Research 15:469-475. 1972.

TURNER, D.M. \& MILLARD, W.A. Leaf-spot of oats, Helminthosporium avenae (Bri. and Cav.) Eid. Annual of Applied Biology 18: 535-559. 1931.

VALÈ, G., TORRIGIANI, E., CATTIVELLI, L. \& DELOGU, G. Molecular study on barley Drechslera graminea interaction. Genetica Polonica 35B:25-30. 1994. 